\title{
The global impact of the transport sectors on atmospheric aerosol in 2030 - Part 2: Aviation
}

\author{
Mattia Righi, Johannes Hendricks, and Robert Sausen \\ Deutsches Zentrum für Luft- und Raumfahrt (DLR), Institut für Physik der Atmosphäre, Oberpfaffenhofen, Germany \\ Correspondence to: Mattia Righi (mattia.righi@dlr.de)
}

Received: 13 October 2015 - Published in Atmos. Chem. Phys. Discuss.: 2 December 2015

Revised: 14 March 2016 - Accepted: 29 March 2016 - Published: 11 April 2016

\begin{abstract}
We use the EMAC (ECHAM/MESSy Atmospheric Chemistry) global climate-chemistry model coupled to the aerosol module MADE (Modal Aerosol Dynamics model for Europe, adapted for global applications) to simulate the impact of aviation emissions on global atmospheric aerosol and climate in 2030. Emissions of short-lived gas and aerosol species follow the four Representative Concentration Pathways (RCPs) designed in support of the Fifth Assessment Report of the Intergovernmental Panel on Climate Change. We compare our findings with the results of a previous study with the same model configuration focusing on year 2000 emissions. We also characterize the aviation results in the context of the other transport sectors presented in a companion paper. In spite of a relevant increase in aviation traffic volume and resulting emissions of aerosol (black carbon) and aerosol precursor species (nitrogen oxides and sulfur dioxide), the aviation effect on particle mass concentration in 2030 remains quite negligible (on the order of a few $\mathrm{ng} \mathrm{m}^{-3}$ ), about 1 order of magnitude less than the increase in concentration due to other emission sources. Due to the relatively small size of the aviation-induced aerosol, however, the increase in particle number concentration is significant in all scenarios (about $1000 \mathrm{~cm}^{-3}$ ), mostly affecting the northern mid-latitudes at typical flight altitudes $(7-12 \mathrm{~km})$. This largely contributes to the overall change in particle number concentration between 2000 and 2030, which also results in significant climate effects due to aerosol-cloud interactions. Aviation is the only transport sector for which a larger impact on the Earth's radiation budget is simulated in the future: the aviation-induced radiative forcing in 2030 is more than doubled with respect to the year 2000 value of $-15 \mathrm{~mW} \mathrm{~m}^{-2}$ in all scenarios, with a maximum value of $-63 \mathrm{~mW} \mathrm{~m}^{-2}$ simulated for RCP2.6.
\end{abstract}

\section{Introduction}

Civil aviation is the fastest growing transport mode. Lee et al. (2009) reported a growth of air traffic (in terms of revenue per kilometre) of $38 \%$ between 2000 and 2007, while several future scenarios (Kahn Ribeiro et al., 2007) project an increase in $\mathrm{CO}_{2}$ emissions from aviation of about a factor of 2 between 2010 and 2030, with an even faster increase up to 2050. Although this sector accounts for a relatively small fraction of the global $\mathrm{CO}_{2}$ emissions from fossil fuels $(2.6 \%$ in the year 2004; Lee et al., 2010), it has a substantial impact on climate due to a wide range of non- $\mathrm{CO}_{2}$ effects, including ozone formation and methane destruction via $\mathrm{NO}_{x}$ emissions, direct and indirect aerosol effects from sulfate and black carbon (BC), the formation of contrail and contrailcirrus clouds, and the perturbation of natural cirrus clouds due to BC (see Sausen et al., 2005; Lee et al., 2010, and references therein). In addition to impacts on the climate, emissions of particulate matter from aircraft and related activities at and in the vicinity of airports can have detrimental effects on air quality and related impacts on human health (Herndon et al., 2004, 2008; Schürmann et al., 2007). The study by Barrett et al. (2010) also found significant impacts on air quality from aircraft emissions at cruise level, but the resulting health impacts have been questioned by H. Lee et al. (2013a).

In this work, we analyse the aviation impact on aerosol and climate for different future scenarios. We focus on the year 2030 in the four Representative Concentration Pathways (RCPs; Moss et al., 2010; van Vuuren et al., 2011a). These scenarios were developed in support of the Fifth Assessment Report of the Intergovernmental Panel on Climate Change (IPCC AR5). The results presented here complement those of Righi et al. (2015, hereafter R15), focusing on land transport and shipping. These two papers together represent 
a follow-up study of Righi et al. (2013, hereafter R13). In $\mathrm{R} 13$, we considered year 2000 emissions and performed several sets of model simulations to estimate transport impacts on atmospheric aerosol, to quantify the uncertainty in the effects on particle number concentrations related to the assumed particle size distribution of emitted particles, and to explore the non-linearities in the aerosol response to the perturbations induced by transport emissions. Concerning aviation, the R13 study revealed that aircraft emissions perturb the aerosol distribution in the upper troposphere, particularly at northern mid-latitudes, and also have significant impacts near the surface, mainly due to activities near airports. The aviation-induced impact on the Earth's radiation budget was found to be quite uncertain, strongly dependent on the assumed size distribution of particles emitted by aircraft. R13 estimated a radiative forcing (RF) in the range of -70 to $2.4 \mathrm{~mW} \mathrm{~m}^{-2}$. The by far largest part of this effect was attributed to low clouds, lying much below the typical emission altitude, in line with the results by Gettelman and Chen (2013) and, more recently, Kapadia et al. (2015).

The numerical experiments in this work have been conducted using the EMAC-MADE global aerosol model (see R13 and references therein), which is able to track both aerosol mass and number perturbations as well as simulate the aerosol-cloud and aerosol-radiation interactions, hence allowing the estimation of aerosol RF effects. In addition to the global effects, we also analyse specific regions where aviation emissions are expected to change significantly compared to 2000, as a consequence of changes in the transport patterns. Since we focus on the relative contribution of aviation to global aerosol and climate, changes in the background concentrations due to the effect of the anthropogenic emissions from other sectors are shown as well. Finally, we note that in the present study only the changes in the emissions of short-lived species (aerosol and precursor gases) are considered, whereas the investigation of the impact of a changing climate on aerosol distribution is not accounted for (we refer to Pye et al., 2009; Kloster et al., 2009; Megaritis et al., 2013, for a discussion on this topic). For this reason, we drive the model using year 2000 conditions for long-lived species $\left(\mathrm{CO}_{2}\right.$ and methane) and radiatively active gases (other than water vapour), and use meteorological data for the period 1996-2005 to nudge the model dynamics. The analysis in this paper focuses on the same period.

The future aviation impacts were investigated by Huszar et al. (2013), based on the previous IPCC SRES A1B scenario (Nakicenovic et al., 2000) up to 2100, but only considering gaseous compounds (both $\mathrm{CO}_{2}$ and non- $\mathrm{CO}_{2}$ ), which were found to have a small climate impact. Unger et al. (2013) discussed the future effects of aviation-induced aerosol, following RCP4.5 for the background combined with several aviation emission scenarios. They found that cooling effects induced by short-lived compounds can neutralize or even overcome the $\mathrm{CO}_{2}$ warming, depending on the time horizon under consideration. That study, however, did not take into account the RF due to aerosol-cloud interactions, which we found to be significant for year 2000 emissions, when considering low-level clouds, and potentially much larger than the $\mathrm{CO}_{2}$ forcing (R13). Olivié et al. (2012) found a positive climate impact of non- $\mathrm{CO}_{2}$ compounds from aviation following SRES A1B up to 2100. Their model accounts for both direct and indirect effects of aerosols, but the indirect effect is limited to the sulfate component, which may lead to an underestimation of the total indirect effect. Our study therefore represents a step forward since it includes a more complete representation of the aerosol indirect effect, including the recently reported aviation effect on low clouds, in the framework of the most recent RCP scenarios. Including the four RCPs in our experiments also allows us to provide a more complete analysis of the future development of aviation impacts on aerosol and climate.

This paper is organized as follows. A brief overview of the EMAC-MADE model system and its setup, including the considered emissions is provided in Sect. 2. The impact of aviation on the atmospheric aerosol distribution and aerosol burdens is discussed in Sect. 3, while Sect. 4 presents the corresponding aerosol-induced climate impacts. The main conclusions are summarized in Sect. 5.

\section{Model setup, emission inventories and model simulations}

The simulations of this work are performed with the ECHAM (European Centre Hamburg general circulation model) MESSy (Modular Earth Submodel System) Atmospheric Chemistry (EMAC) model, coupled with the Modular Aerosol Dynamics submodel for Europe (MADE), adapted for global applications. We refer to R13 and R15 for a more detailed description of the model system and its configuration, here we only summarize its main features. MADE describes the aerosol population by means of three lognormal aerosol modes (Aitken, accumulation, and coarse) and eight aerosol species: black carbon (BC), particulate organic matter (POM), nitrate $\left(\mathrm{NO}_{3}\right)$, ammonium $\left(\mathrm{NH}_{4}\right)$, sulfate $\left(\mathrm{SO}_{4}\right)$, mineral dust, sea salt and aerosol water. To reduce the computational burden, the chemistry setup is based on a simplified mechanism, including basic tropospheric background chemistry $\left(\mathrm{NO}_{x}-\mathrm{HO}_{x}-\mathrm{CH}_{4}-\mathrm{CO}-\mathrm{O}_{3}\right.$ chemistry) and the sulfur cycle. The model is able to simulate the competition for ammonium between the sulfate and nitrate formation processes, which is particularly important in the upper troposphere, as we will show in Sect. 3. The model setup adopted in this study also includes aerosol-radiation and aerosolcloud couplings (Lauer et al., 2007), which are essential for quantifying the aerosol impacts on climate. The first is realized by explicitly calculating aerosol optical properties online based on the Mie theory and using them to drive the radiation calculations (see also Pozzer et al., 2012). The latter follows the Abdul-Razzak and Ghan (2000) parameterization 
to simulate the number of activated cloud droplets as an input to the two-moment cloud scheme by Lohmann et al. (1999) and Lohmann (2002). This enables tracking of cloud particle number concentration and its aerosol-induced changes. It is important to mention that the current model setup does not include the representation of heterogeneous freezing processes in ice clouds (this is intended to be the subject of a follow-up study).

All model experiments are performed with a T42L19 resolution (corresponding to $2.8^{\circ} \times 2.8^{\circ}$ in the horizontal) and 19 vertical layers up to $10 \mathrm{hPa}$, and covering a period of 10 years. The model dynamics (temperature, winds, and logarithm of surface pressure) is nudged using the data from the European Centre for Medium-Range Weather Forecast (ECMWF). This minimizes the dynamical differences between the different experiments and allows a significant signal to be extracted even with a relatively limited number of simulated years.

The model's ability to reproduce the vertical aerosol distribution was evaluated by Aquila et al. (2011), using observational data from several aircraft campaigns over the globe. They concluded that the representation of aerosol mass and number concentrations in the UTLS (upper tropospherelower stratosphere) by EMAC-MADE is reasonably good.

We have applied the CMIP5 (Climate Model Intercomparison Project - Phase 5) emission data sets developed by Lamarque et al. (2010) in support of the IPCC and the four RCPs for the future projection in 2030 (Moss et al., 2010; van Vuuren et al., 2011a). As extensively discussed in R15, the RCPs are defined based on the projected value of the global anthropogenic RF in 2100 and includes four projections with increasing climate impact: RCP2.6, RCP4.5, RCP6.0, and RCP8.5. The RCPs are climate-policy scenarios, but they are quite limited in terms of air-quality projections, as they do not cover the full range of air pollution mitigation policies currently available (Chuwah et al., 2013). As pointed out by R15 and several other studies (e.g. Takemura, 2012), they often show an opposite behaviour between long-lived and short-lived species. The CMIP5 aviation emissions data include $\mathrm{NO}_{x}$ (an important aerosol nitrate precursor) and $\mathrm{BC}$. We further derive $\mathrm{SO}_{2}$ emissions by scaling the $\mathrm{BC}$ emissions with the ratio of the emission factors of the two species at each altitude level (see R13 for details) in all scenarios. This results in total aviation emissions of $0.168 \mathrm{Tg}\left(\mathrm{SO}_{2}\right) \mathrm{a}^{-1}$ in 2000, which compares well with the ACCRI/AEDT value of $0.221 \mathrm{Tg}\left(\mathrm{SO}_{2}\right) \mathrm{a}^{-1}$ in 2006 (Brasseur et al., 2015). We further assume that $2.2 \%$ of the sulfur mass is emitted as primary $\mathrm{SO}_{4}$, based on Jurkat et al. (2011).

Moreover, since the aerosol submodel used for this study (MADE) simulates both aerosol mass and number, it requires number emissions to be provided as input: these have been calculated from mass emissions under specific assumptions on the size distribution of emitted particles. In R13, we analysed an additional set of parameters to test the effect of such assumptions on the simulated impacts of transport on aerosol distributions and climate. To reduce the computational burden, in the present study we have performed experiments assuming only one set of parameters to describe the size distribution of emitted particles. That is, we have used the same size distribution parameters as for the reference case in R13 and applied them to both emitted primary aerosol species, i.e. $\mathrm{BC}$ and primary $\mathrm{SO}_{4}$, in order to derive number emissions from mass. Compared to the other cases assumed in R13, this is a middle-of-the-road choice, based on measured values by Petzold et al. (1999) in the engine exhaust of a B737300 aircraft, and combined with an assumption for fuel sulfur content $\left(0.8 \mathrm{~g}\left(\mathrm{SO}_{2}\right) \mathrm{kg}_{\text {fuel }}^{-1}\right)$ as suggested in the assessment by Lee et al. (2010).

All of the RCPs project a steady increase in aviation emissions of short-lived compounds between 2000 and 2030. This is significantly different from the other two transport sectors discussed in R15, for which a decrease in emissions of aerosol and aerosol precursors was found in most regions for all scenarios: this is a consequence of air pollution control measures (land transport) and sulfate reduction policies (shipping), which lead to emission reductions despite the steady growth in traffic volumes of these two sectors. For large commercial aircraft, however, no significant changes in technology are foreseen for aircraft engines in the near future, as no viable alternative to jet engines has been identified (Sims et al., 2014). Therefore the growing emissions are essentially a direct consequence of increasing air traffic volumes. The development and the implementation of new technologies in the aviation sector is more difficult than for road traffic and shipping, given the much higher safety standard required by aircraft, the relatively long lifetime of the commercial fleet (about three decades), and the necessity to keep costs low (Kahn Ribeiro et al., 2007). Current efforts to minimize the climate impact of aviation are focusing on the improvements of fuel efficiency, modification of aircraft routes (Grewe et al., 2014a) and introduction of low-sulfur fuels (Unger, 2011; Bock, 2014).

As there are relevant regional differences in the distribution of air traffic, we have analysed the emission changes between 2000 and 2030 on the global scale and in three different regions of intense air traffic: the flight routes connecting the USA and Europe (the so-called North Atlantic flight corridor), the routes between Europe and Asia, and between Asia and the USA (Fig. 1). The relative changes between 2030 and 2000 in the emissions of aviation-relevant compounds are depicted in Fig. 2. Since $\mathrm{SO}_{2}$ emissions are derived here by rescaling $\mathrm{BC}$ emissions using the altitudedependent ratio of the emission factors of the two components, the relative changes between 2000 and 2030 of BC and $\mathrm{SO}_{2}$ are similar in Fig. 2. This also applies to number emissions (NUM), which are derived from the mass emissions of $\mathrm{BC}$ and primary $\mathrm{SO}_{4}$ (as a fraction of $\mathrm{SO}_{2}$ ).

The largest increases are projected for the flight connections between Europe and Asia (lower-left panel of Fig. 2), mostly due to the fast-growing economies of South East 


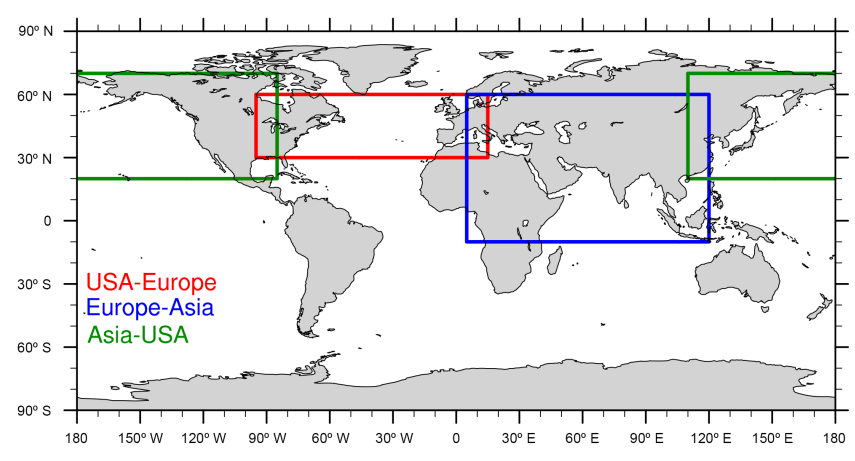

Figure 1. The regions selected for the analysis of the aviation impacts.

Asia, which drives an increase in air traffic volumes. To a lesser extent, this also applies to the Asia-USA connections (lower-right panel). Aviation emissions in RCP4.5 (Thomson et al., 2011) and RCP8.5 (Riahi et al., 2011) were both based on the QUANTIFY inventories (Lee et al., 2010). In RCP6.0 (Masui et al., 2011) the spatial distribution for the year 2000 (Lamarque et al., 2010) was simply scaled with global total emissions, with the consequence that the relative changes are identical in the different regions. The very high increase in BC emissions in RCP2.6 (van Vuuren et al., $2011 \mathrm{~b}$ ) is due to the fact that, in this scenario, the emissions were calculated for total transport and then split among the three sectors (road, shipping and aviation): this split was based on the time-dependent shares of each sector for each species, again according to QUANTIFY. The aviation share for BC in QUANTIFY is characterized by a large increase between 2000 and 2030 (about an order of magnitude for all scenarios, not shown), which explains the large increase in $\mathrm{BC}$ emissions in RCP2.6 given in Fig. 2. Given these considerations, RCP4.5 and RCP8.5 can be regarded as more reliable concerning aviation emissions, since they are based on actual transport-oriented scenarios from QUANTIFY. The aviation projections in the other two RCPs are constructed on basic assumptions using very simplified scalings. The resulting projections should therefore be interpreted with care. For completeness, in the present study we will discuss the results from all RCPs, but we will point out inconsistencies when appropriate.

To estimate the effects of aviation on atmospheric aerosol and on climate, we have performed two model simulations for each RCP (thus a total of eight simulations): a reference experiment (REF) including all emission sources and a sensitivity simulation (NOAIRC) with aviation emissions completely switched off. This allows estimation of the aviation impact $\Delta^{\mathrm{AIRC}}$ in a given RCP as

$\Delta_{\mathrm{RCP}}^{\mathrm{AIRC}}=\mathrm{REF}_{\mathrm{RCP}}-\mathrm{NOAIRC}_{\mathrm{RCP}}$.

This approach could have some limitations due to nonlinearities in the response of the system to the emission perturbation. For the aviation sector, however, R13 found that the impact of the non-linearities is small. The aviation effects calculated for the year 2030 are related to the effects in the year 2000, as simulated by R13, in terms of the changes $D^{\text {AIRC }}$ in aviation-induced surface-level concentrations between 2000 and 2030 for the different scenarios. In analogy to R15, for a given RCP this is given by the difference

$D_{\mathrm{RCP}}^{\mathrm{AIRC}}=\Delta_{\mathrm{RCP}}^{\mathrm{AIRC}}-\Delta_{2000}^{\mathrm{AIRC}}$.

To provide a more complete view on the changes in aviationinduced aerosols, we relate this quantity to the total changes in concentration (i.e. from all sources),

$D_{\mathrm{RCP}}^{\mathrm{ALL}}=\mathrm{REF}_{\mathrm{RCP}}-\mathrm{REF}_{2000}$,

and to the changes in the concentrations induced by other (non-aviation) sources:

$D_{\mathrm{RCP}}^{\mathrm{OTHER}}=\mathrm{NOAIRC}_{\mathrm{RCP}}-\mathrm{NOAIRC}_{2000}$.

Note that, of course, $D_{\mathrm{RCP}}^{\mathrm{ALL}}=D_{\mathrm{RCP}}^{\mathrm{AIRC}}+D_{\mathrm{RCP}}^{\mathrm{OTHER}}$.

\section{Aviation impacts on aerosol in 2030}

The aviation impacts on $\mathrm{BC}, \mathrm{SO}_{4}, \mathrm{NO}_{3}$ and particle number concentrations in fine mode (i.e. $\lesssim 1 \mu \mathrm{m}$, sum of the Aitken and accumulation mode) are plotted in Figs. 3, 4, 5 and 6, respectively. We consider zonally averaged fields from the surface to the UTLS. As a reference for comparison, the first row depicts the year 2000 results from R13 showing the concentrations induced by all sources (left), by aviation only (middle) and by other (non-aviation) sources (right). R13 showed that the aviation impact on particle mass concentration is quite negligible, being around $0.1 \mathrm{ng} \mathrm{m}^{-3}$ for $\mathrm{BC}, 2-5 \mathrm{ng} \mathrm{m}^{-3}$ for $\mathrm{SO}_{4}$, and $2-3 \mathrm{ng} \mathrm{m}^{-3}$ for $\mathrm{NO}_{3}$. The relevance of these impacts, however, also depends on the simulated background aerosol concentrations in the UTLS, which for $\mathrm{BC}$ is known to be biased high in most global models (Schwarz et al., 2013) and, to a lesser extent, in EMACMADE (Aquila et al., 2011). The aviation impact is much larger on particle number concentration, in particular in the northern mid-latitudes between 200 and $300 \mathrm{hPa}$, contributing about $30-40 \%$ of total concentration in this region. This is due to the relatively small size of the particles emitted by aviation (around $25 \mathrm{~nm}$ in our simulations).

The other rows of Figs. 3-6 show the changes between 2000 and 2030 in the concentrations induced by all sources (left), by aviation only (middle) and by other (non-aviation) sources (right). For $\mathrm{BC}$ (Fig. 3), $\mathrm{SO}_{4}$ (Fig. 4) and $\mathrm{NO}_{3}$ (Fig. 5), the contribution of the aviation sector to the mass concentration changes remains small, as it is clear from the comparison of the left (all sources) and the right (nonaviation sources) columns. A noticeable feature is the 0.1$0.3 \mathrm{ng} \mathrm{m}^{-3}$ increase in aviation-induced $\mathrm{BC}$ concentration for RCP2.6 (Fig. 3, second row). This contributes to increase the overall $\mathrm{BC}$ concentration in the tropopause region of the 

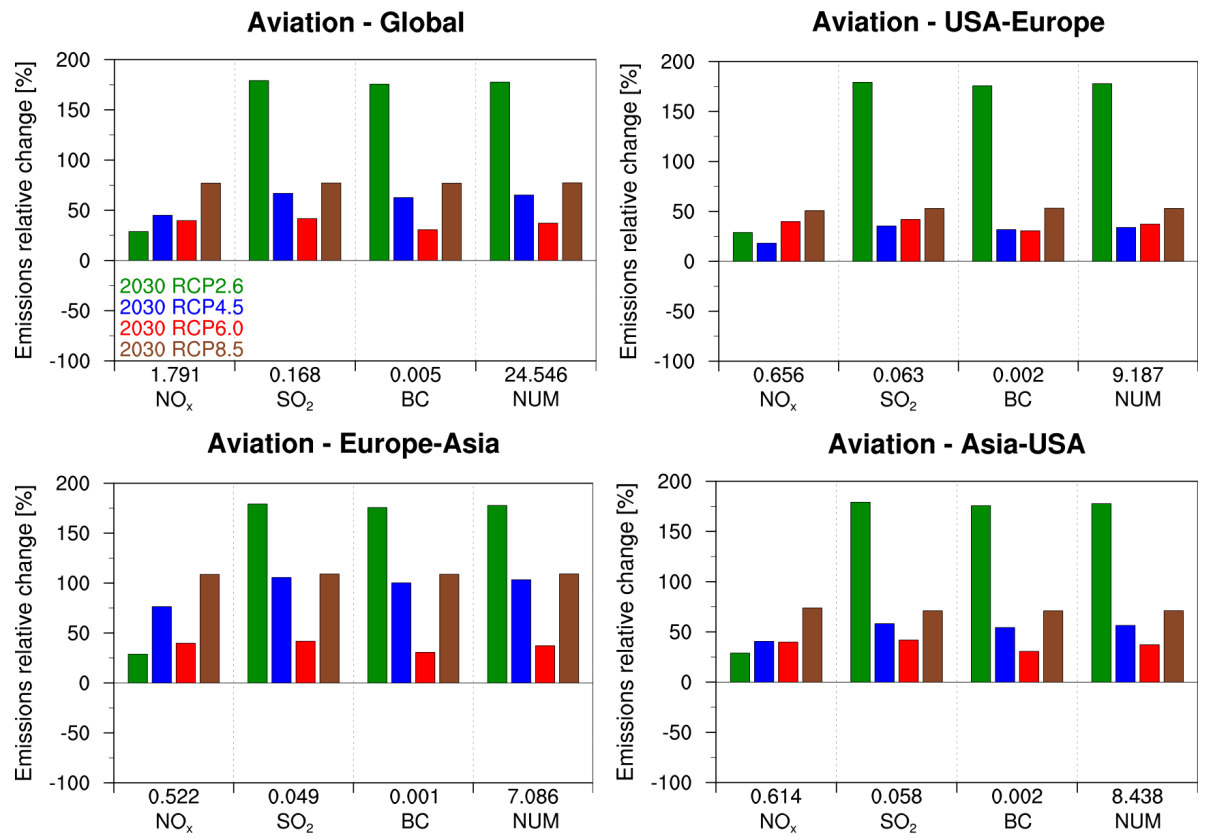

Figure 2. Relative changes in the emissions from aviation in the year 2030 with respect to 2000, for the four RCP scenarios. The changes are displayed globally (top left) and for the regions defined in Fig. 1. Total emissions for the year 2000 are indicated at the bottom of each panel, in units of $\mathrm{Tg}$ (species) $\mathrm{a}^{-1}$ for $\mathrm{SO}_{2}$ and $\mathrm{BC}, \mathrm{Tg}(\mathrm{NO}) \mathrm{a}^{-1}$ for $\mathrm{NO}_{x}$, and $10^{25}$ particles $\mathrm{a}^{-1}$ for particle numbers (NUM).

Northern Hemisphere (left panel), which would be otherwise characterized by a decrease (right panel). In the other scenarios, the pattern of aviation-induced $\mathrm{BC}$ is similar but the perturbations are clearly smaller than in RCP2.6 and mostly below $0.1 \mathrm{ng} \mathrm{m}^{-3}$. In these scenarios, changes are relevant only in the upper troposphere. RCP2.6 is the only scenario showing a significantly increasing impact of aviation on $\mathrm{BC}$ concentration close to the surface, with mean values of $0.1-$ $0.3 \mathrm{ng} \mathrm{m}^{-3}$ around $30^{\circ} \mathrm{N}$. This is more than a factor of 3 larger than the year 2000 impact, and is even more important given that the impact of other sources is getting smaller over the same time period. This could be an issue for airpollution control in the vicinity of major airports. However, due to the reasons discussed in Sect. 2, it should be questioned whether the assumptions of high aviation emission shares in RCP2.6 are realistic. Changes in aviation-induced aerosol sulfate (Fig. 4, middle column) range between 3 and $10 \mathrm{ng} \mathrm{m}^{-3}$ and are largest in RCP2.6 but scarcely counteract the overall decrease driven by other sources (right column), which is typically around -30 to $-100 \mathrm{ng} \mathrm{m}^{-3}$. Another interesting aspect is the negative value for aerosol nitrate in Fig. 5 , between -3 and $-10 \mathrm{ng} \mathrm{m}^{-3}$ : this is a typical effect of the $\mathrm{NH}_{3}$-limited environment in the UTLS (Unger et al., 2013; R13) and is due to the competition between nitrate and sulfate for the available ammonium. We lastly note that the changes in the background concentrations as induced by the other sectors (right column of Figs. 3-5) can be quite different among the RCPs. This of course has an impact on the background chemistry, especially for the secondary particles such as nitrate and sulfate. This means that the changes in aerosol concentrations discussed above are not always controlled by aircraft emissions only, but may also be due to the emission changes in the other sectors.

The increase in mean aviation-induced particle number concentration (Fig. 6), on the other hand, is quite strong in all scenarios, with values of the order of $1000 \mathrm{~cm}^{-3}$ in the northern mid-latitude UTLS. In this domain, the aviation emissions significantly contribute to the overall changes in particle number concentration between 2000 and 2030, leading to a large increase $\left(1000-3000 \mathrm{~cm}^{-3}\right)$, in particular for RCP2.6 and RCP8.5.

To further explore the aviation effects, Fig. 7 presents the contribution of the aviation sector to the UTLS burden of different species in various regions. The largest increase in the relative contribution to the burden is found again for RCP2.6, as expected from the emission changes (Fig. 2). The impact of aviation on the number burden is far larger than for the mass and is projected to grow for all scenarios in 2030, in particular for RCP2.6, showing a more than doubled relative contribution compared to 2000 , for both size modes. The highest values, around 55-75\%, are simulated for the North Atlantic flight corridor (USA-Europe routes, top-right panel) for the particles in the Aitken mode. As discussed in R13, the simulated impacts of aviation on aerosol number concentration in the upper troposphere are not very sensitive to the assumed size distribution of emitted particles but rather to the sulfur content of aviation fuels. The large increase simulated for 2030 scenarios therefore has to be considered as an upper 


\section{Aviation impacts on $\mathrm{BC}$}
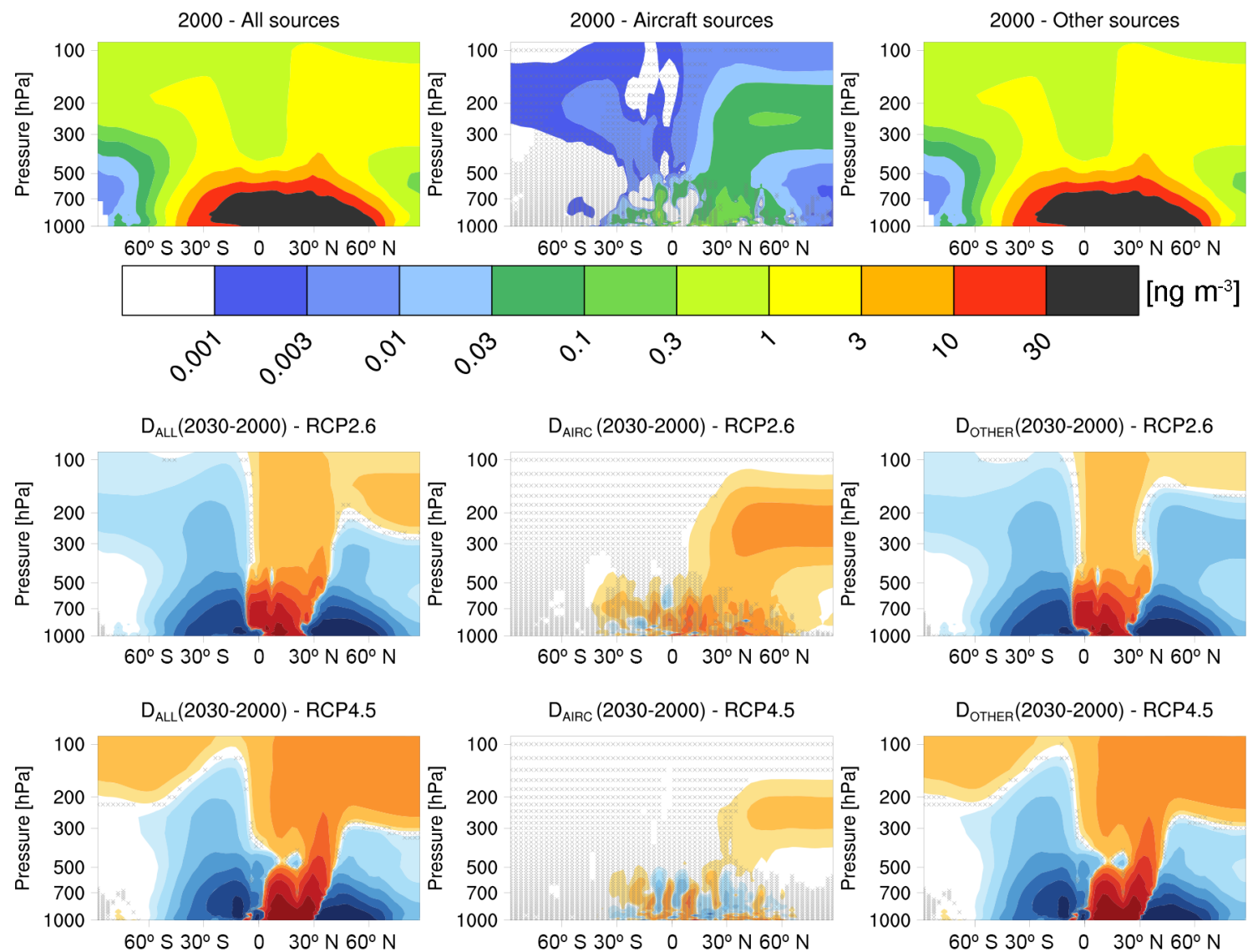

$\mathrm{D}_{\text {AIRC }}(2030-2000)-\mathrm{RCP} 4.5$
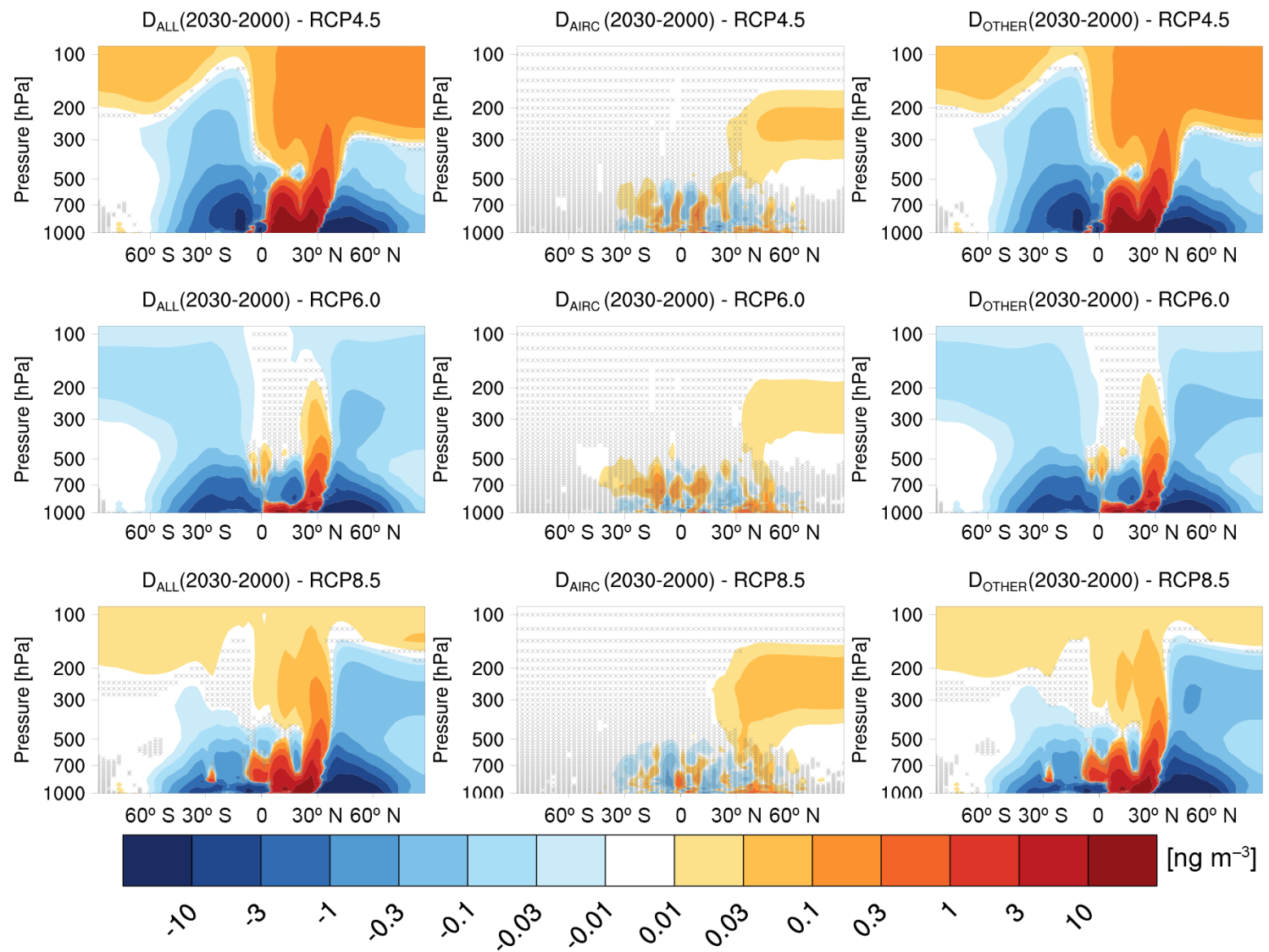

Figure 3. Annual average zonal mean concentrations of BC. The first row shows the results for year 2000 emissions: total concentration $\left(\mathrm{REF}_{2000}\right.$, left), the concentration induced by aviation $\left(\Delta_{2000}^{\mathrm{AIRC}}\right.$, middle $)$ and the concentration induced by other sources $(\mathrm{NOAIRC} 2000$, right). The lower four rows show the changes in these quantities between 2000 and 2030 for the four RCPs, as given in Eqs. (2)-(4). Grid points are hatched where the difference is not statistically significant according to a univariate $t$ test (5\% error probability). 


\section{Aviation impacts on $\mathrm{SO}_{4}$}
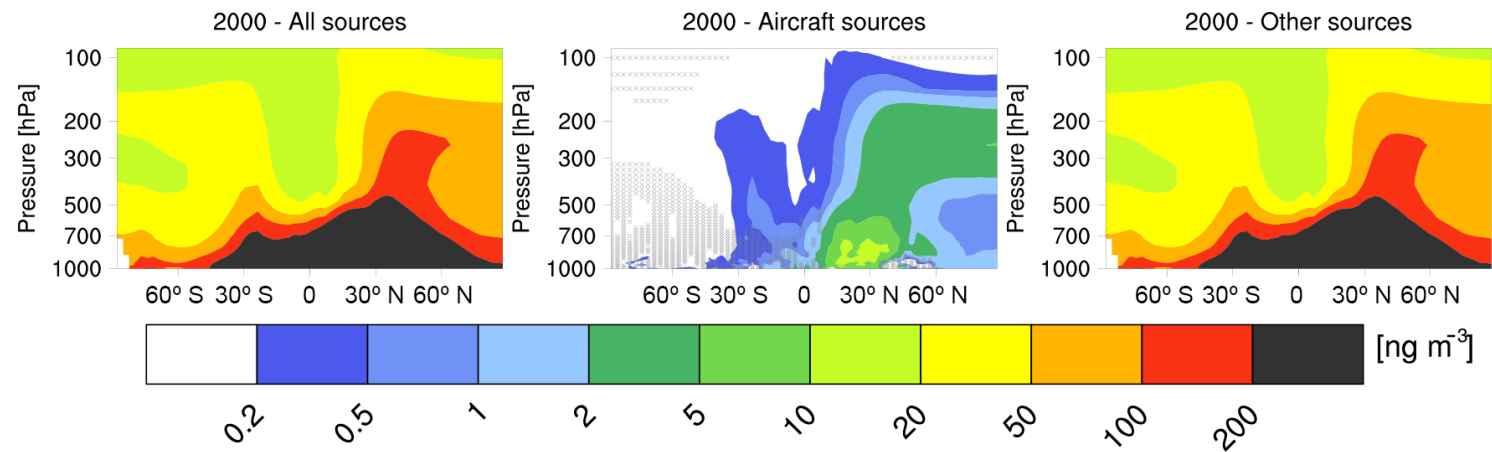
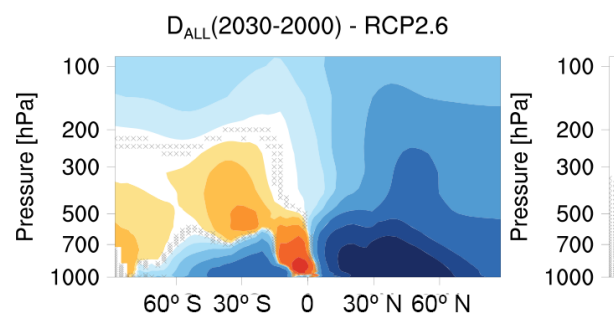

$D_{\text {AIRC }}(2030-2000)-R C P 2.6$

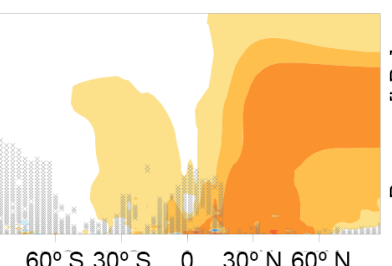

$\mathrm{D}_{\text {AIRC }}(2030-2000)$ - RCP4.5
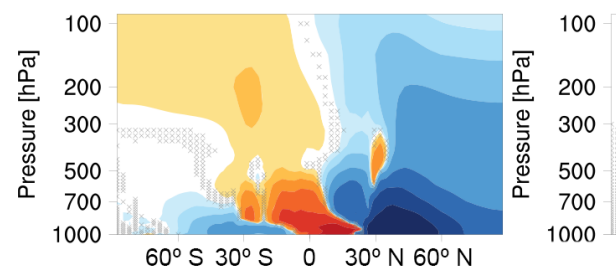

$D_{\text {ALL }}(2030-2000)-R C P 6.0$

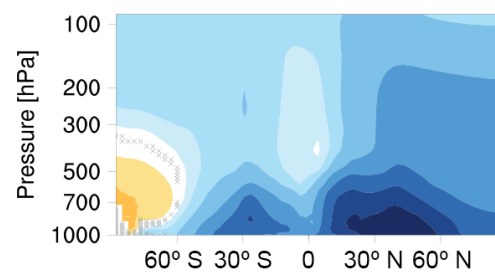

$D_{\text {ALL }}(2030-2000)$ - RCP8.5
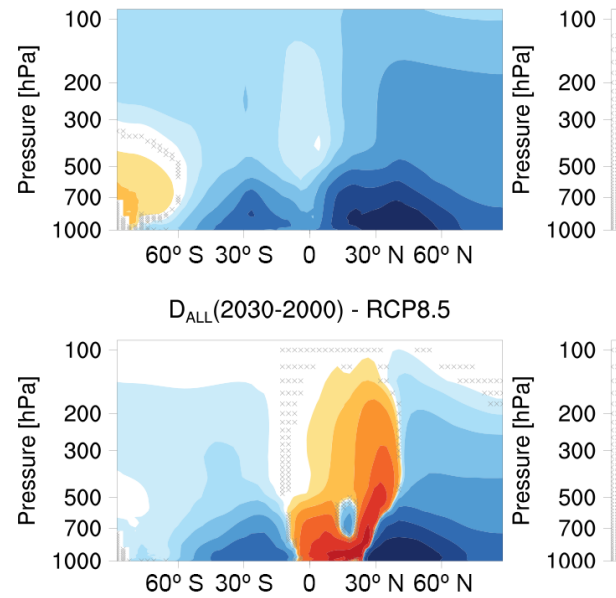

$60^{\circ} \mathrm{S} 30^{\circ} \mathrm{S} \quad 0 \quad 30^{\circ} \mathrm{N} 60^{\circ} \mathrm{N}$

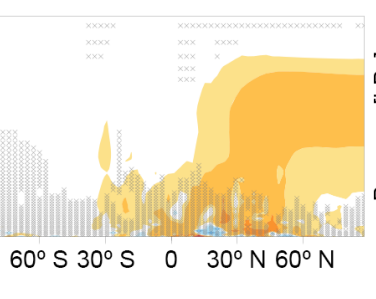

$D_{\text {AIRC }}(2030-2000)-R C P 6.0$

$60^{\circ} \mathrm{S} 30^{\circ} \mathrm{S} \quad 0 \quad 30^{\circ} \mathrm{N} 60^{\circ} \mathrm{N}$

$D_{\text {AIRC }}(2030-2000)-R C P 8.5$

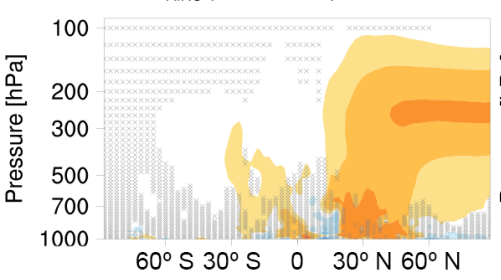

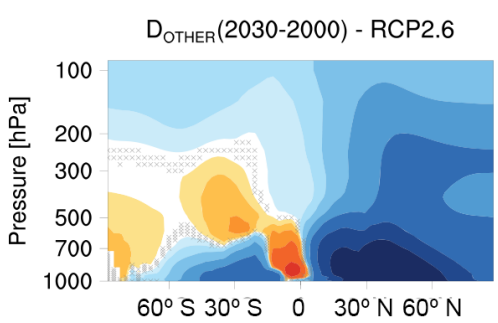
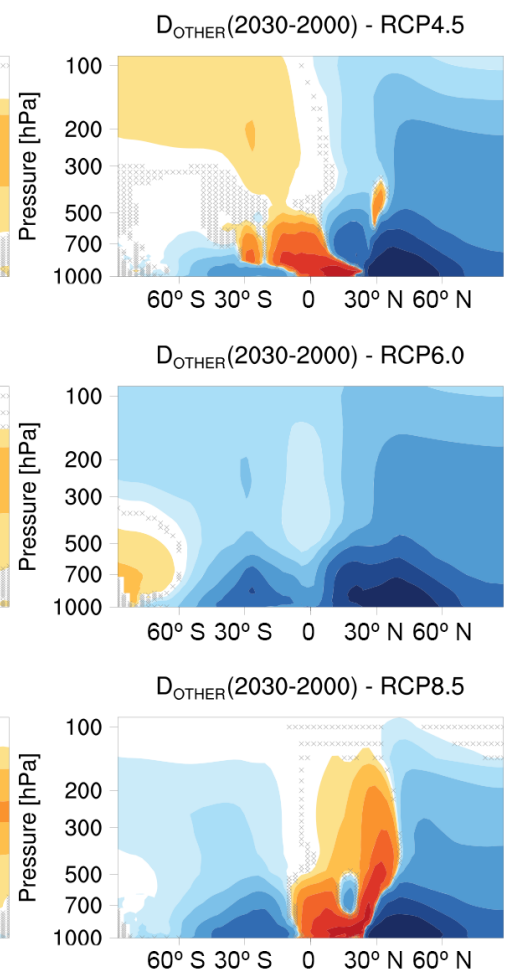

[ng $\mathrm{m}^{-3}$ ]

Figure 4. As in Fig. 3 but for aerosol sulfate concentration. 


\section{Aviation impacts on $\mathrm{NO}_{3}$}
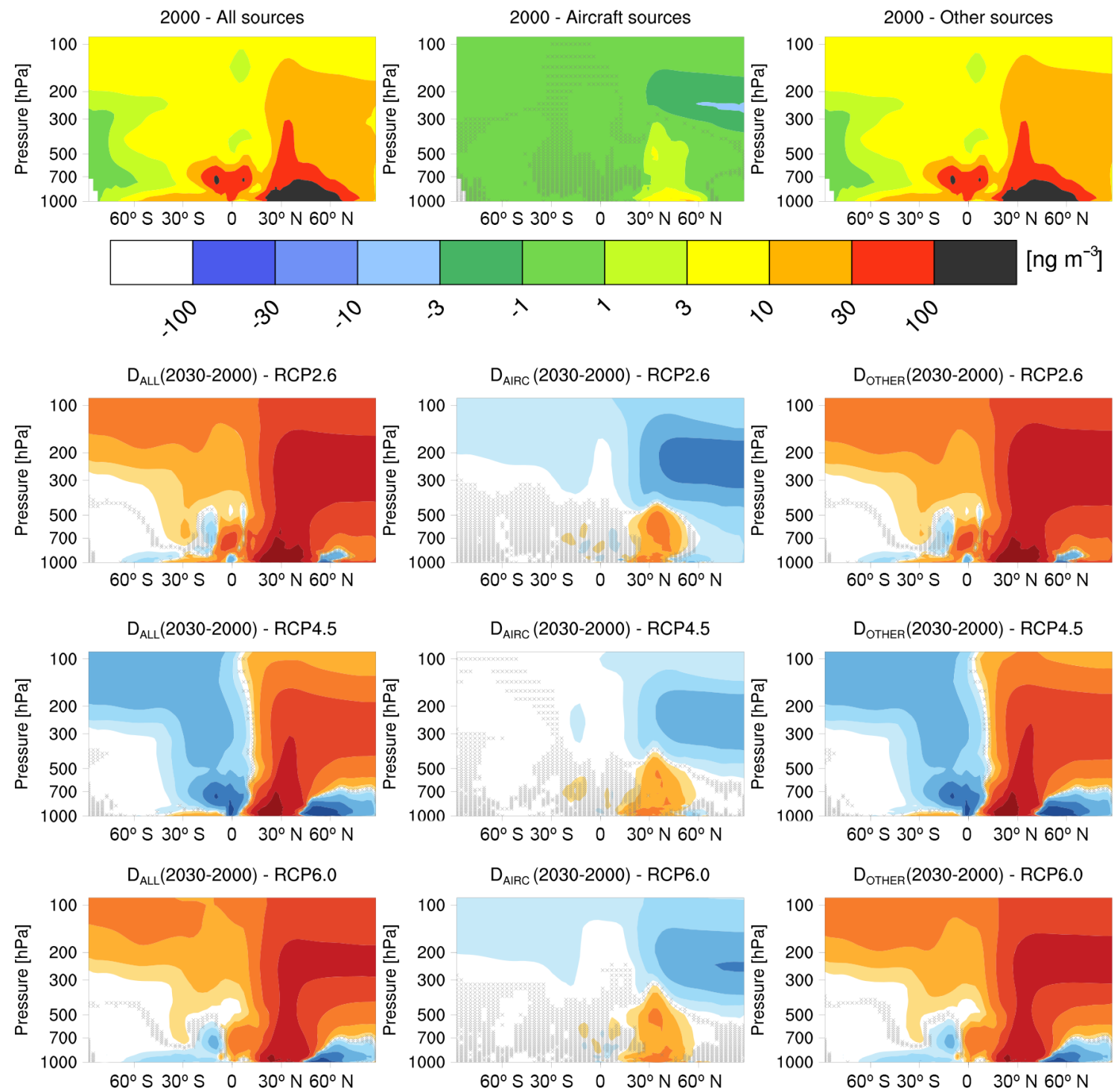

$D_{\text {AIRC }}(2030-2000)-R C P 6.0$

$\mathrm{D}_{\text {OTHER }}(2030-2000)$ - RCP6.0
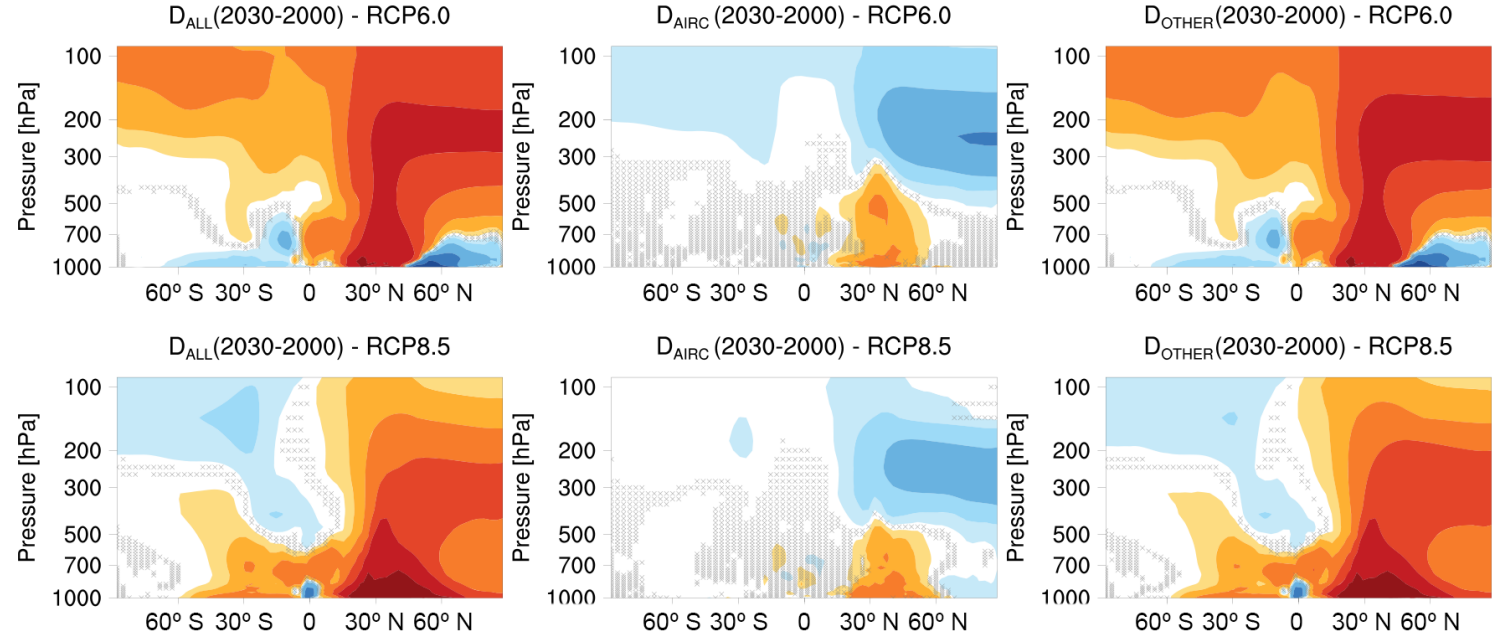

$\mathrm{D}_{\text {AIRC }}(2030-2000)$ - RCP8.5
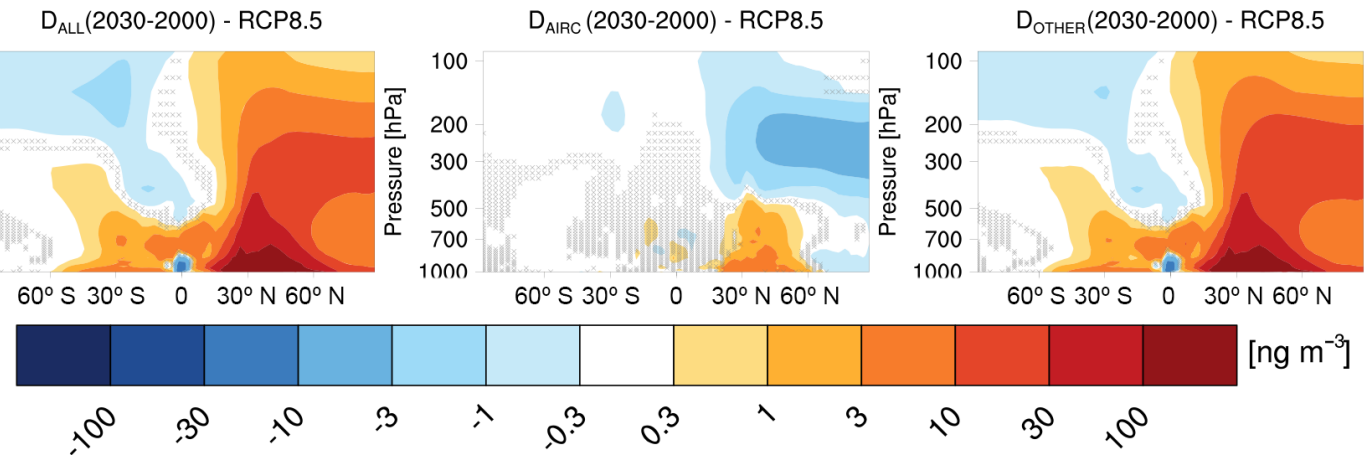

Figure 5. As in Fig. 3 but for aerosol nitrate concentration. 


\section{Aviation impacts on $\mathbf{N}_{\text {tot }}$}
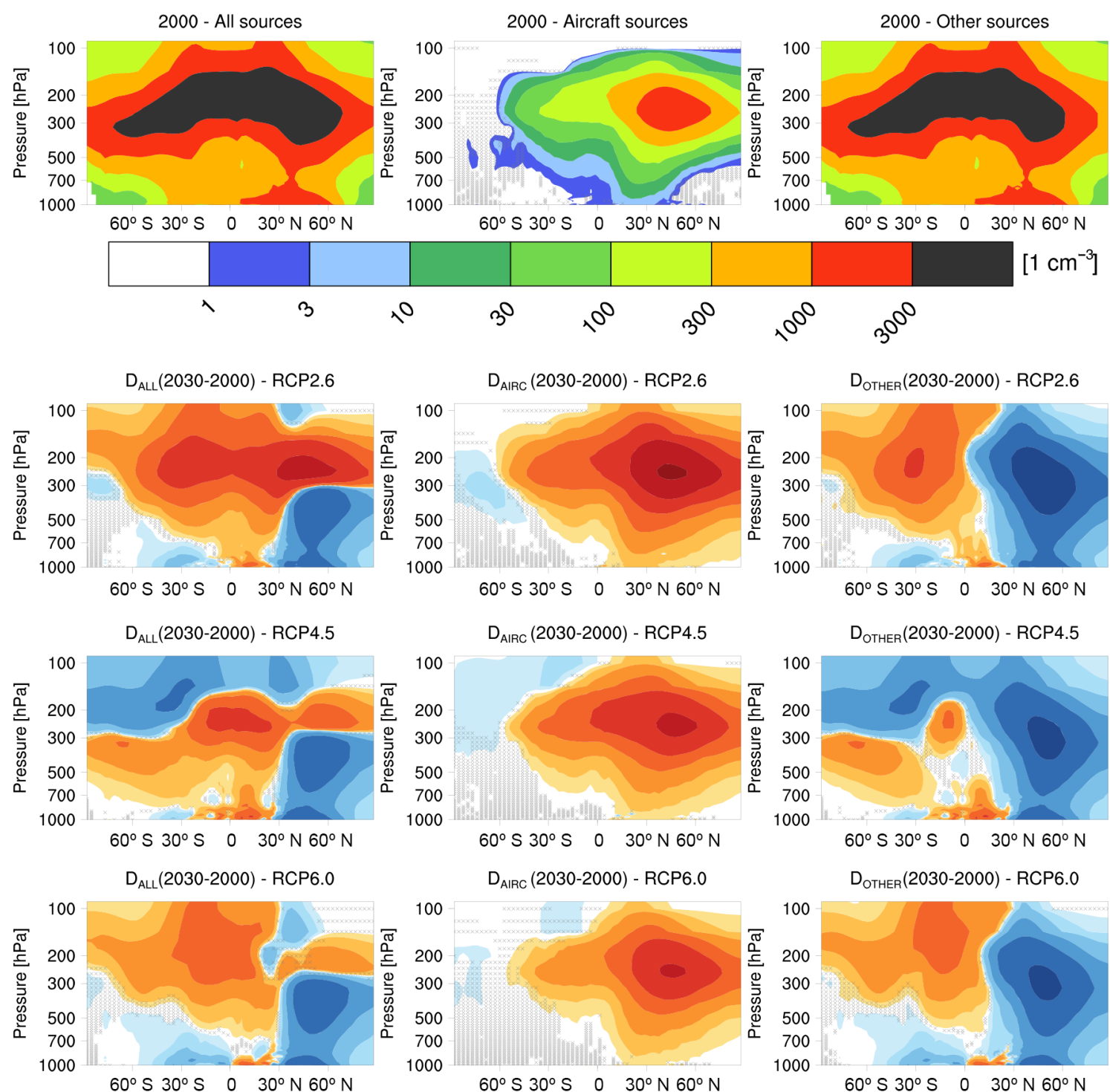

$D_{\text {AIRC }}(2030-2000)-R C P 6.0$

$\mathrm{D}_{\text {OTHER }}(2030-2000)$ - RCP6.0

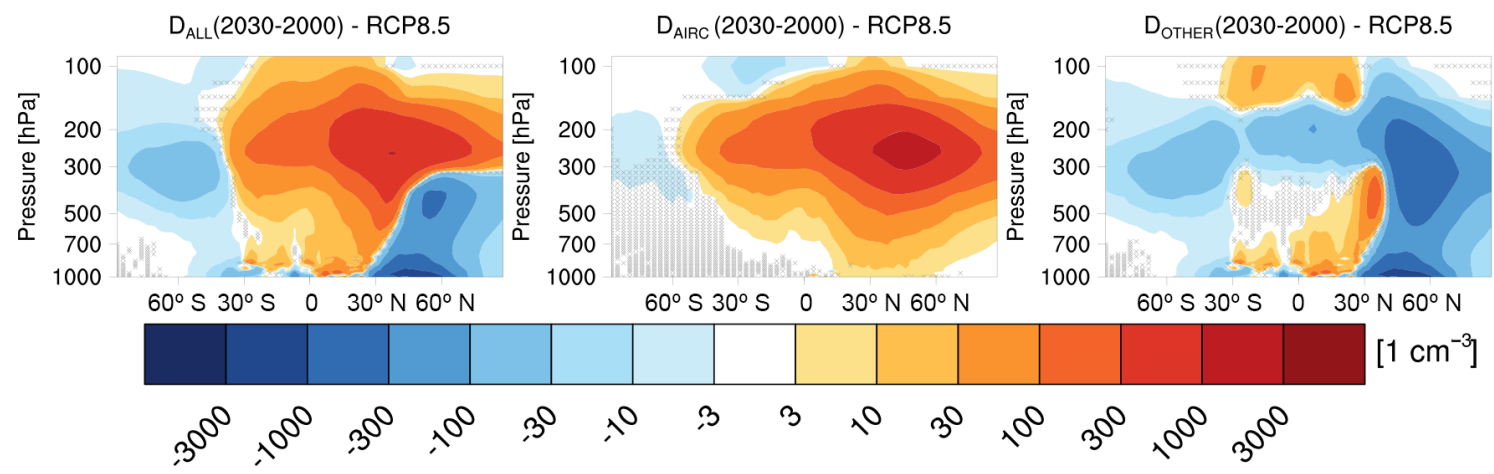

Figure 6. As in Fig. 3 but for fine particle $(\lesssim 1 \mu \mathrm{m}$, sum of the Aitken- and accumulation-mode particles) number concentrations. 

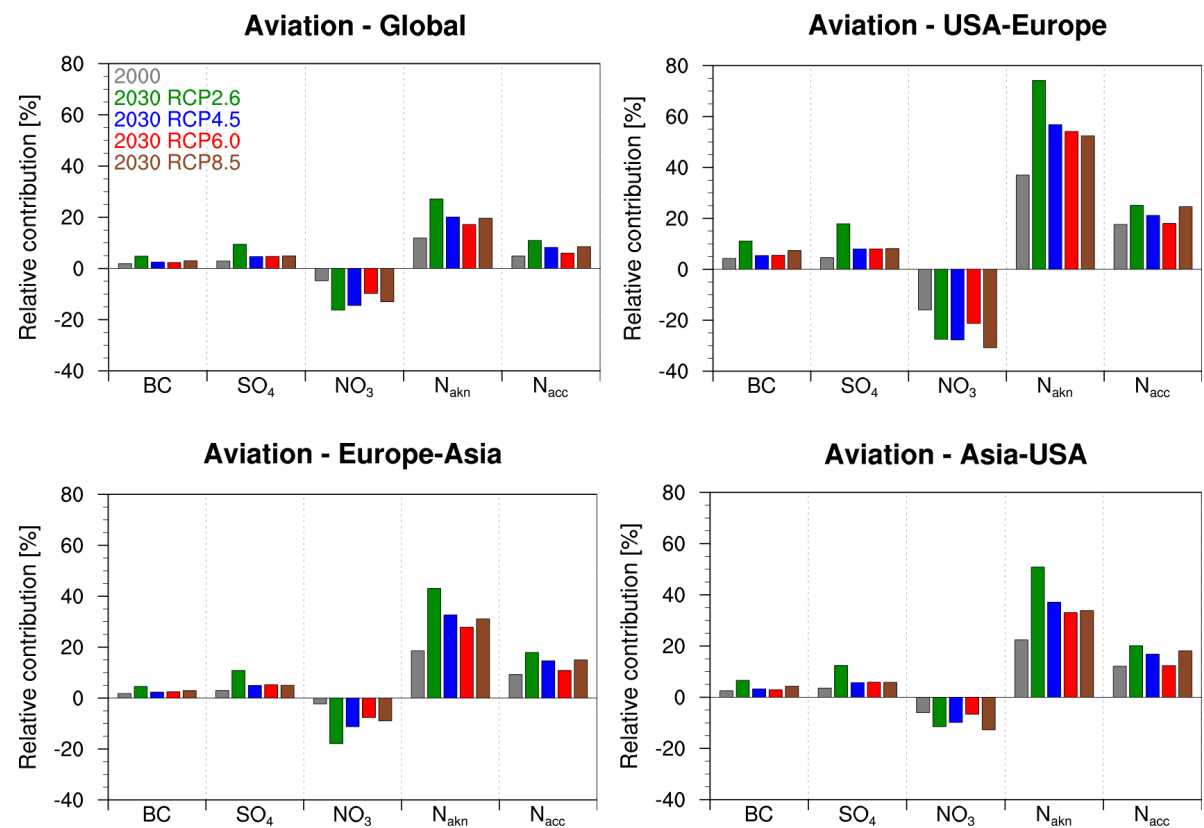

Figure 7. Relative contributions of aviation to the average mass and number burdens of selected aerosol species and different particle size modes (Aitken and accumulation mode). Results are shown for the year 2000 and for the four RCP scenarios in 2030 . The values are integrated in model layers 7 to $9(\sim 8-13 \mathrm{~km})$ globally and in three different regions (defined in Fig. 1).

limit, since much smaller impacts on particle number burden can be expected if low-sulfur fuels are considered for the future. It is also interesting to note that the largest burdens are not found in the routes to and from Asia, where the emissions were larger, but for the USA-Europe route. This could be due to the relatively clean background in this region, due the lower emission from other sectors being transported upwards, an effect similar to the relatively low impact of land transport in Asia reported by R13.

The large changes in particle number concentration induced by aviation emissions also have a large impact on climate, as we discuss in the next section.

\section{Aviation impacts on Earth's radiation budget}

To quantify the aviation-induced aerosol RF we follow the method outlined by Lohmann and Feichter (2005) and Schulz et al. (2006) and consider the changes in the radiative fluxes at the top of the atmosphere. We include both the longwave and the shortwave radiation in this calculation and analyse all-sky and clear-sky fluxes separately. The clear-sky flux is determined online by the model by neglecting clouds in the radiative flux calculations. Through comparison of the allsky and the clear-sky effects, an estimate of the aviationinduced cloud RF can be inferred.

The results for the year 2000 (R13, reference case) and for the four RCPs in 2030 are presented in Fig. 8. In R13, we conducted two additional sensitivity simulations to quantify the uncertainties in the RF related to (i) the assumption

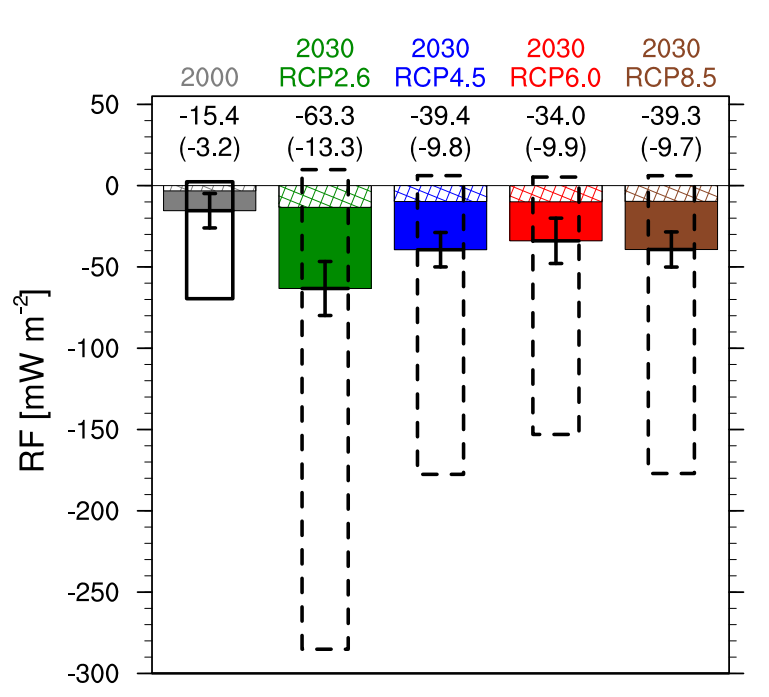

Figure 8. Global mean all-sky RF resulting from aviation emissions in the year 2000 (grey bar) and for the four RCP scenarios in 2030 (coloured bars). The hatched part of each bar is the corresponding clear-sky forcing, calculated neglecting the radiative effects of clouds. The numerical values of the all-sky (clear-sky) forcing are shown on top of each bar in units of $\mathrm{mW} \mathrm{m}^{-2}$. The whiskers represent the $95 \%$ confidence interval with respect to the interannual variability. The boxes correspond to the uncertainty range derived from the assumption on the size distribution of emitted particles and fuel sulfur content, as calculated by R13 for the year 2000 (solid) and rescaled here to the 2030 values (dashed). 
on the size distribution of emitted particles and (ii) the aviation fuel-sulfur content. The first point was addressed in a simulation (NUC) where an additional nucleation mode for the emitted primary sulfate particles was considered, while a simulation (LOW) with a much lower fuel sulfur content ( 0.0052 instead of $\left.0.8 \mathrm{~g}\left(\mathrm{SO}_{2}\right) \mathrm{kg}_{\text {fuel }}^{-1}\right)$ was performed to address the second point. As mentioned in Sect. 2, in order to reduce the computational burden, this analysis is not repeated here. Only the reference case of R13 is simulated for the RCP scenarios in 2030. Nevertheless, we estimate the RF uncertainty for the 2030 results by simply rescaling them according to the uncertainty range calculated for 2000 . These ranges are shown as open boxes in Fig. 8. This rescaling assumes that the same relative uncertainty can be applied to 2000 and 2030 . On the one hand, this is reasonable since no fundamental changes in the aviation engine technology are expected in this time period. On the other hand, however, there are some limitations. The upper limit of this estimate (LOW experiment, which implicitly represents a low-sulfur scenario) was found to be non-significant in R13; therefore, even the sign of the RF in this case is uncertain, while the lower limit (NUC experiment) could be overestimated by this rescaling. Non-linearities in the system response to such large emission perturbation might reduce the actual lower limit of the RF estimate for 2030 presented here. Addressing these issues will require additional experiments and will be the focus of future analyses.

Given the results of R15 for land transport and shipping, aviation is the only transport sector for which an increasing impact of aerosol on the radiation budget is simulated. RCP2.6 is the scenario with the largest increase, shifting the all-sky forcing from $-15 \mathrm{~mW} \mathrm{~m}^{-2}$ in 2000 to $-63 \mathrm{~mW} \mathrm{~m}^{-2}$ in 2030 , while values between about -34 and $-39 \mathrm{~mW} \mathrm{~m}^{-2}$ are calculated for the other scenarios. The total forcing is mostly driven by cloud effects, and the large increase with respect to 2000 can be explained by the large increase in aviation sulfate emissions (Fig. 2). The bulk of the aviationinduced all-sky RF is generated in the northern mid-latitudes (Fig. 9): this was expected given the distribution of the aviation-induced perturbation in aerosol particle number discussed in the previous section and depicted in Fig. 6.

Considering the uncertainties associated with the size distribution, extremely large values can be estimated, up to $-285 \mathrm{~mW} \mathrm{~m}^{-2}$ for RCP2.6, if the NUC (nucleation) size distribution of R13 is assumed, characterized by a large number of sulfate particles emitted in the nucleation mode. Some of these particles can eventually grow and act as cloud condensation nuclei which affect climate by altering the cloud microphysical structure. Note that, according to the results of $\mathrm{R} 13$, the bulk of the RF simulated here is due to perturbation of liquid clouds at lower levels, below the typical emission altitude. Two possible mechanisms can explain this effect: (i) emissions during climb and approach or (ii) downward transport of particles from flight levels, particularly due to downwelling of air masses in the subtropical jet regions.
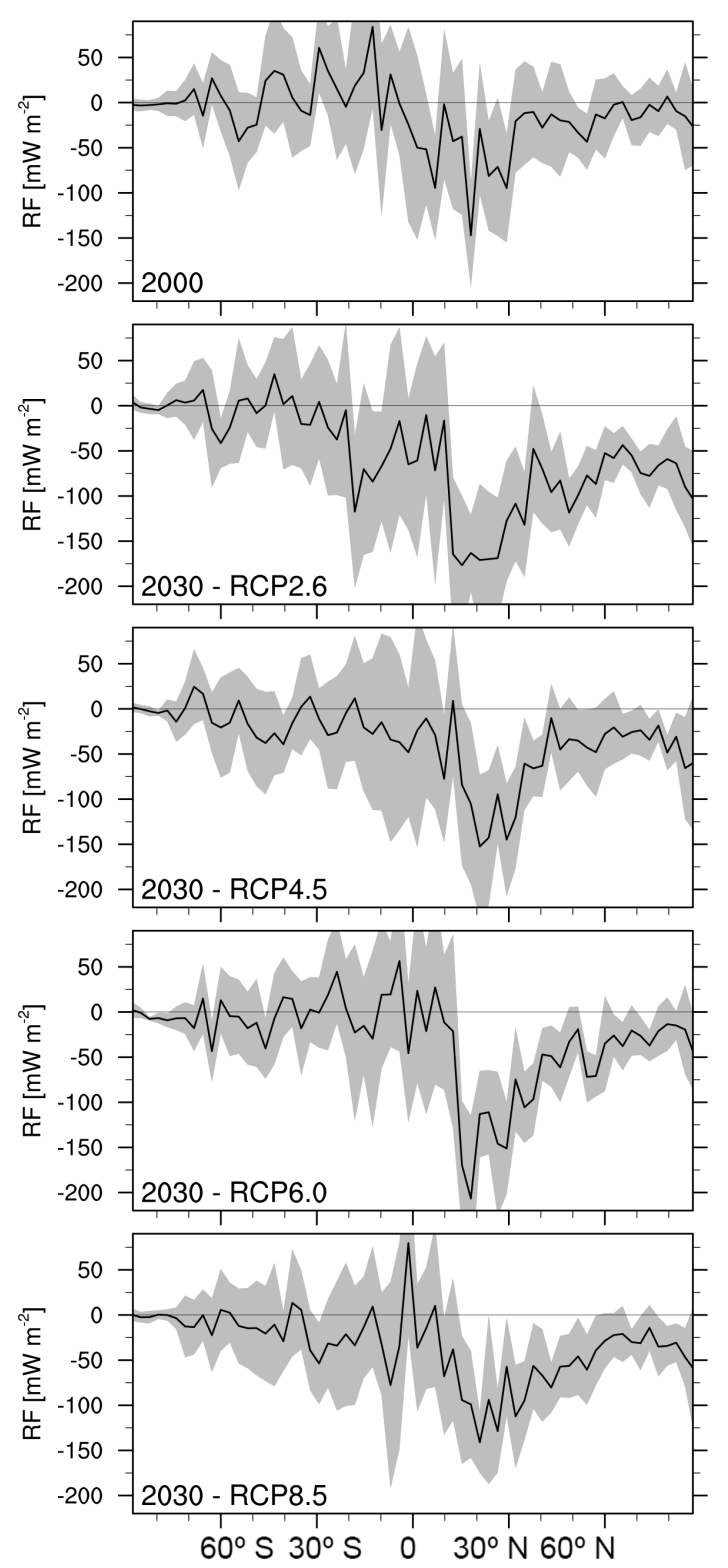

Figure 9. Zonal mean all-sky RF resulting from aviation emissions in the year 2000 and 2030 for the four RCP scenarios (from top to bottom). The grey shadings represent the $95 \%$ confidence interval with respect to the interannual variability.

The model results of Barrett et al. (2010, 2012), based on the GEOS-Chem model, indeed show a typical downward transport path for aviation-induced aerosol and aerosol precursors around $30^{\circ} \mathrm{N}$, which is consistent with the pattern of aviation-induced changes in number concentrations simulated here (Fig. 6, middle column), hence supporting the latter mechanism.

Pitari et al. (2015) estimated the direct aerosol effect from aviation using the REACT4C inventory for 2006 (Søvde et al., 2014). They found a RF of $-3.4 \mathrm{~mW} \mathrm{~m}^{-2}$ (for sulfate) and $0.86 \mathrm{~mW} \mathrm{~m}^{-2}$ (for BC). This results in a total direct 
$\mathrm{RF}$ for aviation of $-2.54 \mathrm{~mW} \mathrm{~m}^{-2}$ which compares very well with our clear-sky RF for the year 2000 of $-3.2 \mathrm{~mW} \mathrm{~m}^{-2}$, although clear-sky forcing is only a proxy for the aerosol direct effect and our estimates also include the effect of aerosol nitrate. Their estimate for the indirect effect cannot be compared with ours as they only considered the effect of $\mathrm{BC}$ on cirrus clouds, which is not covered here. The future impacts of aviation emissions on climate have also been simulated by Unger et al. (2013), using RCP4.5 for background emissions and considering three different technology scenarios for aviation in 2050 . However, their study only considered the direct aerosol effect (sulfate, nitrate and black carbon), reporting a range of $[-65 ;-20] \mathrm{mW} \mathrm{m}^{-2}$. The only study to date considering the effect of aviation sulfate emissions on warm clouds in future scenarios is the one by Chen and Gettelman (2016), who applied the CAM5 model with the RCP4.5 and RCP8.5 emissions, reporting a maximum sulfate-driven cooling effect of $-160 \mathrm{~mW} \mathrm{~m}^{-2}$ in 2050 , a factor of about 4 times larger than the 2006 value. This is line with our findings of a factor of $\sim 2.6$ increase between 2000 and 2030 in the same scenarios (Fig. 8).

\section{Conclusions}

Using the EMAC global climate-chemistry model coupled to the aerosol module MADE, we quantified the impact of aviation on atmospheric aerosol and climate in the year 2030 under the four RCPs. In terms of both aerosol load and climate impacts, we found all scenarios to project an increasing impact of aviation in the future, with RCP2.6 being the most extreme one. Aviation-induced concentration of black carbon and aerosol sulfate will increase in the UTLS and close to the surface, but their overall impact on the atmospheric composition will still be small compared to the other anthropogenic sources. We simulated a strong impact of the aviation sector on particle number concentration in the upper-troposphere mid-latitudes. This is significantly larger than for the year 2000 and counteracts the decrease in particle number concentration due to other sources, leading to an overall increase in this region. The aerosol-driven climate impact of aviation in 2030 results in a global cooling effect, albeit with large uncertainties depending on the assumptions on emitted particle size distribution and fuel sulfur content, which even affect the sign of the resulting RF. Compared to the estimates for the year 2000, aviation-induced aerosol RF is about 2 (RCP6.0) to 4 times (RCP2.6) larger.

Together with Righi et al. (2013) and Righi et al. (2015), this paper concludes a series of three studies on the global impact of land transport, shipping and aviation on atmospheric aerosol and climate in the year 2000 and in the RCP scenarios in 2030. The present study reveals that aviation is the only transport sector for which an increasing impact is simulated in the future. This is essentially due to the strong growth of air traffic volumes, which counteracts the effects of implementing significant technological improvements to reduce the emissions, as is happening for the other sectors (e.g. emission control on vehicle engines and fuel regulations in shipping). In this set of studies, we also found that transport-induced aerosol particles can efficiently perturb low-level warm clouds, resulting in a strong cooling effect on the Earth's radiation budget, often comparable to or stronger than the warming effect of other compounds, like $\mathrm{CO}_{2}$ and ozone. Future policies addressing the aviation sector should therefore focus on reducing its climate impact. Recent studies suggested a promising approach, based on optimized aircraft routes to reduce climate impacts (Grewe et al., 2014a, b). The focus so far has been on $\mathrm{CO}_{2}$ and nitrogen oxides, but it should be extended to include aerosol effects on clouds, especially warm clouds, as the results of our study suggest. Another possibility to reduced the aviation impact is the replacement of conventional (fossil) fuel by alternative fuels and biofuels. In light of the results presented in this work, the role of sulfur content of aviation fuels will be of particular relevance. This will change the amount of emissions, with potential effects on contrail formation and evolution, as well as indirect cloud effects. The direct effect of BC could also become more relevant in such a case. Hence, detailed knowledge on the combustion process, emissions, and related climate impact of biofuels is required.

The estimate of the global impact of the transport sectors using global aerosol-climate models is still affected by several uncertainties. Some of them have been addressed in our series of papers: we showed, for example, that the parameters describing the size distribution of emitted particles can be critical and can significantly influence the resulting estimates, especially concerning transport-induced aerosol number concentrations and, as a direct consequence, aerosolcloud effects and RF calculations. The parameterization of sub-grid-scale processes is a general issue in global models, due to their coarse spatial resolution. In an extensive parametric study, L. A. Lee et al. (2013b) showed that the sub-grid production of a few per cent mass of sulfate particles in plumes is much more important for the uncertainty on cloud condensation nuclei calculation than the $\mathrm{SO}_{2}$ emissions themselves. This is consistent with our findings for the aviation sector, where a much larger climate impact is simulated when an extra nucleation mode for the emitted primary sulfate particles is considered (see Sect. 4 and R13). We also showed that sulfur content of aviation fuels can play a relevant role in the resulting climate impacts. We estimated this using basic assumptions and two extreme cases, but in the future it will be important to achieve better constraints, also including geographically dependent sulfur emission factors, since the aviation fuel type often depends on the departure airport.

Finally, we reiterate that the model version applied for these studies considers a simplified representation of aerosol effects on ice clouds. Only homogeneous freezing of supercooled liquid aerosol is considered, but heterogeneous nu- 
cleation processes, such as soot-induced ice formation, are neglected. In the future, we will improve this aspect of the model, including heterogeneous nucleation via various processes. This will also require an improved representation of aerosol in the UTLS, which is essential for a correct representation of the aerosol mass and number concentration and hence a more precise estimate of the impact of aviation emissions.

Acknowledgements. This study has been conducted in the framework of the DLR projects VEU and WeCare, and of the EU-FP7 project REACT4C. The aerosol model MADE was originally developed by the University of Cologne, Germany (RIU/EURAD project). We are grateful to the whole MESSy team for the development of EMAC and in particular to Patrick Jöckel for his help with the model setup. We thank Klaus-Dirk Gottschaldt for his valuable comments on the manuscript draft. We appreciate the thorough comments of the three anonymous reviewers, which led to significant improvements in the revised version of this paper.

The article processing charges for this open-access

publication were covered by a Research

Centre of the Helmholtz Association.

Edited by: Y. Balkanski

\section{References}

Abdul-Razzak, H. and Ghan, S. J.: A parameterization of aerosol activation 2. Multiple aerosol types, J. Geophys. Res., 105, 68376844, doi:10.1029/1999JD901161, 2000.

Aquila, V., Hendricks, J., Lauer, A., Riemer, N., Vogel, H., Baumgardner, D., Minikin, A., Petzold, A., Schwarz, J. P., Spackman, J. R., Weinzierl, B., Righi, M., and Dall'Amico, M.: MADE-in: a new aerosol microphysics submodel for global simulation of insoluble particles and their mixing state, Geosci. Model Dev., 4, 325-355, doi:10.5194/gmd-4-325-2011, 2011.

Barrett, S. R. H., Britter, R. E., and Waitz, I. a.: Global mortality attributable to aircraft cruise emissions., Environ. Sci. Technol., 44, 7736-7742, doi:10.1021/es101325r, 2010.

Barrett, S. R. H., Yim, S. H. L., Gilmore, C. K., Murray, L. T., Kuhn, S. R., Tai, A. P. K., Yantosca, R. M., Byun, D. W., Ngan, F., Li, X., Levy, J. I., Ashok, A., Koo, J., Wong, H. M., Dessens, O., Balasubramanian, S., Fleming, G. G., Pearlson, M. N., Wollersheim, C., Malina, R., Arunachalam, S., Binkowski, F. S., Leibensperger, E. M., Jacob, D. J., Hileman, J. I., and Waitz, I. A.: Public health, climate, and economic impacts of desulfurizing jet fuel, Environ. Sci. Technol., 46, 42754282, doi:10.1021/es203325a, 2012.

Bock, L.: Modellierung von Kondensstreifenzirren: Mikrophysikalische und optische Eigenschaften, Ph.D. thesis, LMU München: Faculty of Physics, Munich (Germany), 2014.

Brasseur, G. P., Gupta, M., Anderson, B. E., Balasubramanian, S., Barrett, S., Duda, D., Fleming, G., Forster, P. M., Fuglestvedt, J., Gettelman, A., Halthore, R. N., Jacob, S. D., Jacobson, M. Z., Khodayari, A., Liou, K.-N., Lund, M. T., Miake-Lye, R. C., Minnis, P., Olsen, S., Penner, J. E., Prinn, R., Schumann, U.,
Selkirk, H. B., Sokolov, A., Unger, N., Wolfe, P., Wong, H.W., Wuebbles, D. W., Yi, B., Yang, P., and Zhou, C.: Impact of Aviation on Climate: FAA's Aviation Climate Change Research Initiative (ACCRI) Phase II, B. Am. Meteorol. Soc., in press, doi:10.1175/BAMS-D-13-00089.1, 2015.

Chen, C.-C. and Gettelman, A.: Simulated 2050 aviation radiative forcing, Atmos. Chem. Phys. Discuss., doi:10.5194/acp-2015922, in review, 2016.

Chuwah, C., van Noije, T., van Vuuren, D. P., Hazeleger, W., Strunk, A., Deetman, S., Beltran, A. M., and van Vliet, J.: Implications of alternative assumptions regarding future air pollution control in scenarios similar to the Representative Concentration Pathways, Atmos. Environ., 79, 787-801, doi:10.1016/j.atmosenv.2013.07.008, 2013.

Gettelman, A. and Chen, C.: The climate impact of aviation aerosols, Geophys. Res. Lett., 40, 2785-2789, doi:10.1002/grl.50520, 2013.

Grewe, V., Champougny, T., Matthes, S., Frömming, C., Brinkop, S., Søvde, O. A., Irvine, E. A., and Halscheidt, L.: Reduction of the air traffic's contribution to climate change: A REACT4C case study, Atmos. Environ., 94, 616-625, 2014a.

Grewe, V., Frömming, C., Matthes, S., Brinkop, S., Ponater, M., Dietmüller, S., Jöckel, P., Garny, H., Tsati, E., Dahlmann, K., Søvde, O. A., Fuglestvedt, J., Berntsen, T. K., Shine, K. P., Irvine, E. A., Champougny, T., and Hullah, P.: Aircraft routing with minimal climate impact: the REACT4C climate cost function modelling approach (V1.0), Geosci. Model Dev., 7, 175-201, doi:10.5194/gmd-7-175-2014, 2014b.

Herndon, S. C., Shorter, J. H., Zahniser, M. S., Nelson, D. D., Jayne, J., Brown, R. C., Miake-Lye, R. C., Waitz, I., Silva, P., Lanni, T., Demerjian, K., and Kolb, C. E.: $\mathrm{NO}$ and $\mathrm{NO}_{2}$ emission ratios measured from in-use commercial aircraft during taxi and takeoff, Environ. Sci. Technol., 38, 6078-6084, doi:10.1021/es049701c, 2004.

Herndon, S. C., Jayne, J. T., Lobo, P., Onasch, T. B., Fleming, G., Hagen, D. E., Whitefield, P. D., and Miake-Lye, R. C.: Commercial aircraft engine emissions characterization of in-use aircraft at Hartsfield-Jackson Atlanta International Airport, Environ. Sci. Technol., 42, 1877-1883, doi:10.1021/es072029+, 2008.

Huszar, P., Teyssèdre, H., Michou, M., Voldoire, A., Olivié, D. J. L., Saint-Martin, D., Cariolle, D., Senesi, S., Salas Y Melia, D., Alias, A., Karcher, F., Ricaud, P., and Halenka, T.: Modeling the present and future impact of aviation on climate: an AOGCM approach with online coupled chemistry, Atmos. Chem. Phys., 13, 10027-10048, doi:10.5194/acp-13-10027-2013, 2013.

Jurkat, T., Voigt, C., Arnold, F., Schlager, H., Kleffmann, J., Aufmhoff, H., Schäuble, D., Schaefer, M., and Schumann, U.: Measurements of $\mathrm{HONO}, \mathrm{NO}, \mathrm{NO}_{\mathrm{y}}$ and $\mathrm{SO}_{2}$ in aircraft exhaust plumes at cruise, Geophys. Res. Lett., 38, 1-5, doi:10.1029/2011GL046884, 2011.

Kahn Ribeiro, S., Kobayashi, S., Beuthe, M., Gasca, J., Greene, D., Lee, D., Muromachi, Y., Newton, P., Plotkin, S., Sperling, D., Wit, R., and Zhou, P.: Transport and its infrastructure, in: Climate Change 2007: Mitigation. Contribution of Working Group III to the Fourth Assessment Report of the Intergovernmental Panel on Climate Change, IPCC, edited by: Metz, B., Davidson, O., Bosch, P., Dave, R., and Meyer, L., 323-385, Cambridge University Press, Cambridge, United Kingdom and New York, NY, USA, 2007. 
Kapadia, Z. Z., Spracklen, D. V., Arnold, S. R., Borman, D. J., Mann, G. W., Pringle, K. J., Monks, S. A., Reddington, C. L., Benduhn, F., Rap, A., Scott, C. E., Butt, E. W., and Yoshioka, M.: Impacts of aviation fuel sulfur content on climate and human health, Atmos. Chem. Phys. Discuss., 15, 18921-18961, doi:10.5194/acpd-15-18921-2015, 2015.

Kloster, S., Dentener, F., Feichter, J., Raes, F., Lohmann, U., Roeckner, E., and Fischer-Bruns, I.: A GCM study of future climate response to aerosol pollution reductions, Clim. Dynam., 34, 11771194, doi:10.1007/s00382-009-0573-0, 2009.

Lamarque, J.-F., Bond, T. C., Eyring, V., Granier, C., Heil, A., Klimont, Z., Lee, D., Liousse, C., Mieville, A., Owen, B., Schultz, M. G., Shindell, D., Smith, S. J., Stehfest, E., Van Aardenne, J., Cooper, O. R., Kainuma, M., Mahowald, N., McConnell, J. R., Naik, V., Riahi, K., and van Vuuren, D. P.: Historical (1850-2000) gridded anthropogenic and biomass burning emissions of reactive gases and aerosols: methodology and application, Atmos. Chem. Phys., 10, 7017-7039, doi:10.5194/acp10-7017-2010, 2010.

Lauer, A., Eyring, V., Hendricks, J., Jöckel, P., and Lohmann, U.: Global model simulations of the impact of ocean-going ships on aerosols, clouds, and the radiation budget, Atmos. Chem. Phys., 7, 5061-5079, doi:10.5194/acp-7-5061-2007, 2007.

Lee, D. S., Fahey, D. W., Forster, P. M., Newton, P. J., Wit, R. C. N., Lim, L. L., Owen, B., and Sausen, R.: Aviation and global climate change in the 21st century, Atmos. Environ., 43, 35203537, doi:10.1016/j.atmosenv.2009.04.024, 2009.

Lee, D. S., Fahey, D. W., Forster, P. M., Newton, P. J., Wit, R. C. N., Lim, L. L., Owen, B., and Sausen, R.: Transport impacts on atmosphere and climate: Aviation, Atmos. Environ., 44, 46784734, doi:10.1016/j.atmosenv.2009.06.005, 2010.

Lee, H., Olsen, S. C., Wuebbles, D. J., and Youn, D.: Impacts of aircraft emissions on the air quality near the ground, Atmos. Chem. Phys., 13, 5505-5522, doi:10.5194/acp-13-5505-2013, 2013.

Lee, L. A., Pringle, K. J., Reddington, C. L., Mann, G. W., Stier, P., Spracklen, D. V., Pierce, J. R., and Carslaw, K. S.: The magnitude and causes of uncertainty in global model simulations of cloud condensation nuclei, Atmos. Chem. Phys., 13, 8879-8914, doi:10.5194/acp-13-8879-2013, 2013.

Lohmann, U.: Possible Aerosol Effects on Ice Clouds via Contact Nucleation, J. Atmos. Sci., 59, 647-656, doi:10.1175/15200469(2001)059<0647:PAEOIC>2.0.CO;2, 2002.

Lohmann, U. and Feichter, J.: Global indirect aerosol effects: a review, Atmos. Chem. Phys., 5, 715-737, doi:10.5194/acp-5-7152005, 2005.

Lohmann, U., Feichter, J., Chuang, C. C., and Penner, J. E.: Prediction of the number of cloud droplets in the ECHAM GCM, J. Geophys. Res., 104, 9169-9198, doi:10.1029/1999JD900046, 1999.

Masui, T., Matsumoto, K., Hijioka, Y., Kinoshita, T., Nozawa, T., Ishiwatari, S., Kato, E., Shukla, P., Yamagata, Y., and Kainuma, M.: An emission pathway for stabilization at $6 \mathrm{~W} \mathrm{~m}^{-2}$ radiative forcing, Climatic Change, 109, 59-76, doi:10.1007/s10584-0110150-5, 2011.

Megaritis, A. G., Fountoukis, C., Charalampidis, P. E., Pilinis, C., and Pandis, S. N.: Response of fine particulate matter concentrations to changes of emissions and temperature in Europe, Atmos. Chem. Phys., 13, 3423-3443, doi:10.5194/acp-13-34232013, 2013.
Moss, R. H., Edmonds, J. A., Hibbard, K. A., Manning, M. R., Rose, S. K., van Vuuren, D. P., Carter, T. R., Emori, S., Kainuma, M., Kram, T., Meehl, G. A., Mitchell, J. F. B., Nakicenovic, N., Riahi, K., Smith, S. J., Stouffer, R. J., Thomson, A. M., Weyant, J. P., and Wilbanks, T. J.: The next generation of scenarios for climate change research and assessment, Nature, 463, 747-56, doi:10.1038/nature08823, 2010.

Nakicenovic, N., Alcamo, J., Davis, G., de Vries, B., Fenhann, J., Gaffin, S., Gregory, K., Grübler, A., Jung, T. Y., Kram, T., Lebre La Rovere, E., Michaelis, L., Mori, S., Morita, T., Pepper, W., Pitcher, H., Price, L., Riahi, K., Roehrl, A., Rogner, H.-H., Sankovski, A., Schlesinger, M., Shukla, P., Smith, S., Swart, R., van Rooijen, S., Victor, N., and Dadi, Z.: Special Report on Emissions Scenarios: A Special Report of Working Group III of the Intergovernmental Panel on Climate Change, Cambridge University Press, Cambridge, UK, 2000.

Olivió, D. J. L., Cariolle, D., Teyssèdre, H., Salas, D., Voldoire, A., Clark, H., Saint-Martin, D., Michou, M., Karcher, F., Balkanski, Y., Gauss, M., Dessens, O., Koffi, B., and Sausen, R.: Modeling the climate impact of road transport, maritime shipping and aviation over the period 1860-2100 with an AOGCM, Atmos. Chem. Phys., 12, 1449-1480, doi:10.5194/acp-12-1449-2012, 2012.

Petzold, A., Döpelheuer, A., Brock, C. A., and Schröder, F.: In situ observations and model calculations of black carbon emission by aircraft at cruise altitude, J. Geophys. Res., 104, 22171-22181, doi:10.1029/1999JD900460, 1999.

Pitari, G., Iachetti, D., Di Genova, G., De Luca, N., Søvde, O. A., Hodnebrog, Ø., Lee, D. S., and Lim, L. L.: Impact of Coupled $\mathrm{NO}_{x}$ /Aerosol Aircraft Emissions on Ozone Photochemistry and Radiative Forcing, Atmosphere, 6, 751-782, doi:10.3390/atmos6060751, 2015.

Pozzer, A., de Meij, A., Pringle, K. J., Tost, H., Doering, U. M., van Aardenne, J., and Lelieveld, J.: Distributions and regional budgets of aerosols and their precursors simulated with the EMAC chemistry-climate model, Atmos. Chem. Phys., 12, 961-987, doi:10.5194/acp-12-961-2012, 2012.

Pye, H. O. T., Liao, H., Wu, S., Mickley, L. J., Jacob, D. J., Henze, D. K., and Seinfeld, J. H.: Effect of changes in climate and emissions on future sulfate-nitrate-ammonium aerosol levels in the United States, J. Geophys. Res., 114, D01205, doi:10.1029/2008JD010701, 2009.

Riahi, K., Rao, S., Krey, V., Cho, C., Chirkov, V., Fischer, G., Kindermann, G., Nakicenovic, N., and Rafaj, P.: RCP 8.5 - A scenario of comparatively high greenhouse gas emissions, Climatic Change, 109, 33-57, doi:10.1007/s10584-011-0149-y, 2011.

Righi, M., Hendricks, J., and Sausen, R.: The global impact of the transport sectors on atmospheric aerosol: simulations for year 2000 emissions, Atmos. Chem. Phys., 13, 9939-9970, doi:10.5194/acp-13-9939-2013, 2013.

Righi, M., Hendricks, J., and Sausen, R.: The global impact of the transport sectors on atmospheric aerosol in 2030 - Part 1: Land transport and shipping, Atmos. Chem. Phys., 15, 633-651, doi:10.5194/acp-15-633-2015, 2015.

Sausen, R., Isaksen, I., Grewe, V., Hauglustaine, D., Lee, D. S., Myhre, G., Köhler, M. O., Pitari, G., Schumann, U., Stordal, F., and Zerefos, C.: Aviation radiative forcing in 2000: An update on IPCC (1999), Meteorol. Z., 14, 555-561, doi:10.1127/09412948/2005/0049, 2005. 
Schulz, M., Textor, C., Kinne, S., Balkanski, Y., Bauer, S., Berntsen, T., Berglen, T., Boucher, O., Dentener, F., Guibert, S., Isaksen, I. S. A., Iversen, T., Koch, D., Kirkevåg, A., Liu, X., Montanaro, V., Myhre, G., Penner, J. E., Pitari, G., Reddy, S., Seland, $\varnothing$., Stier, P., and Takemura, T.: Radiative forcing by aerosols as derived from the AeroCom present-day and pre-industrial simulations, Atmos. Chem. Phys., 6, 5225-5246, doi:10.5194/acp-65225-2006, 2006.

Schürmann, G., Schäfer, K., Jahn, C., Hoffmann, H., Bauerfeind, M., Fleuti, E., and Rappenglück, B.: The impact of $\mathrm{NO}_{\mathrm{x}}, \mathrm{CO}$ and VOC emissions on the air quality of Zurich airport, Atmos. Environ., 41, 103-118, doi:10.1016/j.atmosenv.2006.07.030, 2007.

Schwarz, J. P., Samset, B. H., Perring, A. E., Spackman, J. R., Gao, R. S., Stier, P., Schulz, M., Moore, F. L., Ray, E. A., and Fahey, D. W.: Global-scale seasonally resolved black carbon vertical profiles over the Pacific, Geophys. Res. Lett., 40, 5542-5547, doi:10.1002/2013GL057775, 2013.

Sims, R., Schaeffer, R., Creutzig, F., Cruz-Núñez, X., D’Agosto, M., Dimitriu, D., Figueroa Meza, M. J., Fulton, L., Kobayashi, S., Lah, O., McKinnon, A., Newman, P., Ouyang, M., Schauer, J. J., Sperling, D., and Tiwari, G.: Transport, in: Climate Change 2014: Mitigation. Contribution of Working Group III to the Fifth Assessment Report of the Intergovernmental Panel on Climate Change, IPCC, edited by: Metz, B., Davidson, O., Bosch, P., Dave, R., and Meyer, L., 1-117, Cambridge University Press, Cambridge, United Kingdom and New York, NY, USA, 2014.

Søvde, O. A., Matthes, S., Skowron, A., Iachetti, D., Lim, L., Owen, B., Hodnebrog, Ø., Genova, G. D., Pitari, G., Lee, D. S., Myhre, G., and Isaksen, I. S.: Aircraft emission mitigation by changing route altitude: A multi-model estimate of aircraft $\mathrm{NO}_{\mathrm{x}}$ emission impact on $\mathrm{O}_{3}$ photochemistry, Atmos. Environ., 95, 468-479, doi:10.1016/j.atmosenv.2014.06.049, 2014.
Takemura, T.: Distributions and climate effects of atmospheric aerosols from the preindustrial era to 2100 along Representative Concentration Pathways (RCPs) simulated using the global aerosol model SPRINTARS, Atmos. Chem. Phys., 12, 1155511572, doi:10.5194/acp-12-11555-2012, 2012.

Thomson, A. M., Calvin, K. V., Smith, S. J., Kyle, G. P., Volke, A., Patel, P., Delgado-Arias, S., Bond-Lamberty, B., Wise, M. A., Clarke, L. E., and Edmonds, J. A.: RCP4.5: a pathway for stabilization of radiative forcing by 2100 , Climatic Change, 109, 77-94, doi:10.1007/s10584-011-0151-4, 2011.

Unger, N.: Global climate impact of civil aviation for standard and desulfurized jet fuel, Geophys. Res. Lett., 38, 1-6, doi:10.1029/2011GL049289, 2011.

Unger, N., Zhao, Y., and Dang, H.: Mid-21st century chemical forcing of climate by the civil aviation sector, Geophys. Res. Lett., 40, 641-645, doi:10.1002/grl.50161, 2013.

van Vuuren, D. P., Edmonds, J., Kainuma, M., Riahi, K., Thomson, A., Hibbard, K., Hurtt, G. C., Kram, T., Krey, V., Lamarque, J.F., Masui, T., Meinshausen, M., Nakicenovic, N., Smith, S. J., and Rose, S. K.: The representative concentration pathways: an overview, Climatic Change, 109, 5-31, doi:10.1007/s10584-0110148-z, 2011a.

van Vuuren, D. P., Stehfest, E., Elzen, M., Kram, T., Vliet, J., Deetman, S., Isaac, M., Klein Goldewijk, K., Hof, A., Mendoza Beltran, A., Oostenrijk, R., and Ruijven, B.: RCP2.6: exploring the possibility to keep global mean temperature increase below $2{ }^{\circ} \mathrm{C}$, Climatic Change, 109, 95-116, doi:10.1007/s10584-011-0152-3, 2011b. 